\title{
Institutions of health's care. Aspects European and judicial
}

\author{
Piotr Stępniak \\ Poznan University of Medical Sciences, Poland
}

\begin{abstract}
Present paper is then a part of a trend to find the premises for the theory's construction. I will try to combine the point of view presented by social sciences, criminology and medical sciences, what will become a starting point for analysis and in further perspective - for research on some theoretical models.
\end{abstract}

Keywords: European Union, justice, medico-social institutions, convicts' health care.

\section{Introduction}

Health protection for people facing jurisdiction in consequence of different types of crime starts to be an issue of great importance, especially in connection with "social" opening of polish penitentiary system after 1989. Although the problem is vital, polish penitentiary thought seems to pass it over, what can be noticed especially in penitentiary sciences, which focuses mainly on the crisis in penitentiary reeducation [1]. From this point of view the problem is a bit "one-tracked". There are many voices pointing the essence, causes and consequences of the mentioned problem for working with people, who came into collision with the law - in the wide perspective for state's penal policy, but solution proposals are still few. Usually they limit to an analysis of single action programs, description of therapeutic activities in a particular prison etc. This perspective lacks of the possibility to generalize mentioned descriptions of successful experiences to the status of scientific theory. This is the main reason why in Polish penitentiary thought standstill prevails. It causes that instead of extrapolating mentioned programs to a higher level than analytic sentences most of theorists tend to reach to penitentiary classics like Michel Foucault [2] or Erving Goffman [3].

The problem of crisis may be defined as the "problem of crisis in scientific thought" about reeducation, it's aims, elements and methods. The solution, however, requires a new theory of influence adequate to nowadays challenges and standards.

Present paper is then a part of a trend to find the premises for the theory's construction. I will try to combine the point of view presented by social sciences, criminology and medical sciences, what will become a starting point for analysis and in further perspective - for research on some theoretical models.

The issue is not as simple as it may seem - it begins on the level of definition of the reeducation itself. It is a fact that to this day it remains impossible to work out one, universal concept of reeducation. In the face of controversies classics always give the best solution - in their understanding reeducation is the process of change done in persons' personality, which aims to eliminate or reduce social disadaptation. For $\mathrm{S}$. Jedlewski, and especially for Cz. Czapów [4], reeducation is a system of caring, educational and therapeutic actions (influences). It seems that mentioned triad is broad in meaning, so it may refer to different age categories in people affected by these actions. Unfortunately confrontation with "real reeducation " especially penitentiary one falls out not really well.

Therefore, despite the fact that possibility of moral revival in people, who are in collision with the law, is nowadays often remonstrated, what may be argued with opinion that the prison didn't improve anybody 
yet - there appears a question concerning specification of current priorities.

Taking into consideration classical reeducation thought and my former papers on social work [5] I would like to propose here a system of factors influencing people, who are in collision with the penal law:

- Therapy.

- Social reinforcement.

- Education.

It is easy to notice that this system is alike to one presented in my former papers [6], but here appears a legible turn in priorities towards treatment and social support. It goes with trends present in so called "old EU members" especially in United Kingdom and France [7].

More precise characteristics of mentioned actions should be preceded by a comment concerning social reinforcement. So - it can be defined as a supreme aim, which can be realized by i.e. protection of convicts' health. After B. Dubois and K.K. Miley I will present it here as "the way, in which people, institutions and communities obtain control over their lives" [8]. According to J. Rappaport "the idea of reinforcement (authorization) suggests both - person deciding about his/her live and his/her democratic participation in live of community, often realized via institutions like schools, neighborhood, churches and other voluntary organizations. Reinforcement brings psychological sense of control and influence on things that happen with and to a person, it also refers to the possibility of having a real influence on society, politics and law. Therefore it is a multi-level construct, which applies to single citizens and institutions or local communities, it suggests studies on people in a certain context" [9].

Reinforcement is then both - the aim and the process. As an aim it signifies an ultimate state, e.g. when person under charge obtains power to complete integration with surrounding community. As a process it is expressed by facilitating, making possible and favoring or promoting the ability to competent, adaptive functioning. It is obvious that in this process actions aiming to maintain good state of health play leading role. Above mentioned conclusion lays on a belief that: "people, as long as they have proper support from milieu, are fighting, active organisms, able to organize their lives and develop their hidden potentials" [10].

From supporting convicts actions model perspective, direction of efforts to obtain change is determined by basic problem, which is client's "departure" to dregs of society in consequence of committing a crime. In case of juveniles it brings a threat to their physical, mental and social development, so the threat of demoralization, which is often connected with family pathology and upbringing in environment socially downgraded, where health care is usually on a very low level. On latter issue the process of causing change in convict, judged in consequence of getting into collision with penal law, should be oriented.

Initial condition of success is the maintenance relatively good state of convict's health. In already described perspective process of "health repair" should be proceeded on three basic levels:

- Single person work level

- Group work level

- Social institutions level, making no difference for convicts placed in prison, so - in isolation, and those, who are released (especially in the conditions of probation supervision).

The issue of levels needs a few words of comment. It seems that the fact of convict's isolation from society by imprisonment, is not an obstacle for health supporting actions for a convict and family. These actions are complex and may be proceeded simultaneously inside and outsider the prison. The fact that prison system in nowadays more open to society is not meaningless here - this is why the problem of convicts health can not remain hidden from society, as it happened before. Prisons' openness, what is worth emphasizing, enables to include in prisoners supportive actions services and institutions of health care and social assistance, which operate in open environment. Therefore convicts during imprisonment may be interested in cooperation.

Mentioned institutions may also focus on convicts' families. So - casework in health protection is typical for cases commissioned by court. It is taken on a base of legal mandate, like judgment made by court (e.g. absolute imprisonment or conditional stay of the carrying out of a sentence connected with probation). It dominated is old EU member countries and in Poland in 1960s. It pressures direct work with individual. Five basis orientations can be pointed here:

- Traditional, i.e. medical

- Psychosocial

- Functional

- Problem-oriented

- Socio-behavioural.

Focusing on social reeducation of convicts (but formulated individually) is common for all orientations in the work context.

In the middle 1950s in Western Europe some attention focused on taking care of families of justice administration clients. On the beginning working with family was a part of casework. Still quite soon ward's (prisoner 
or person under probation in open environment) behaviour started to be perceived not as a personality product, but as an effect of family interactions. It all started familial approach, which is a basis for framework program of taking care of dynamic system individual (patient) surrounding. British system of helping prisoners based on supporting bonds with family during imprisonment (what is often a difficult situation for relatives, also affecting health [11]) can be an example here.

General familial approach relies on acknowledging the influence of familial processes, roles and the way that state of health in family members affects health of an individual included in executive penal proceedings. On the beginning focus was on individual pathology, but quickly family pathology was centered, especially health negligence - it all caused farming four approaches to work on heath issues with families.

Thus in 1950s psychodynamic approach was used. It involved taking into consideration the influence of family members' personalities on their health and convict's health. In early 1960s theorists initiated approach involving denying the possibility to communicate about health in dysfunctional families. Following was a structure approach, which dominated in 1970s. Its aim was to work with disorganized families and served as a way to study environmental influences, family development stages, and organizational factors like interaction patterns and rules. It served health interventions in cases of family crises using the method of planned, short-term problem solving. In the 1970s eclectic approach to ward's families' health occurred it involved using techniques of evaluation and intervention strategies from different theoretical models, e.g. psychodynamic model, communication theory, structural model or crisis intervention model. Together they presume existence of many factors, which should be taken into consideration by medical and social staff to understand family's functioning, intervention aims and potential possibilities and forms of pro-health actions.

Group-work methods were applied to professional social work in 1930s, and group-work theories were created on 1940s. Group-work is defined as a planned effort made for change, based on a conviction that people experience through interactions and group processes, because group is an organism in which mentioned processes occur on many levels. In other words, people responsible for convicts' health care should use group structure and group processes to evoke change in single group members. Helping practice concerning convicts' health care should then use both - medico-social context of the group itself, and means which are used by group members to sustain or change attitudes, interpersonal relations and develop abilities of effective coping and preserving good state of health in their surroundings. It is necessary to notice that group therapy may be preceded only in little groups.

English author G. Konopka describes in this context group-work as a method of medico-social work. This should help single person to improve functioning in a society through intentional experiencing within a group and lead to more effective coping with one's problems concerning group or community, especially those related with health care [12].

As a method of acting in legal cases in an open environment group-work didn't became popular as much as mentioned above familial approach. One of the main reasons is a peculiar character of criminal circles. They create difficult to modify hermetic systems of values, they are usually closed structures, rarely submitting to interventions. Specific solidarity of its members and following high level of inner integration cause the existence of informal groups, which are an alternative for those created by medico-social staff - directed by administration task groups. Despite all it seems to be a promising method of medico-social work, which meaning will grow with the process of opening prisons' to the society. Prisons were the place where group therapy proved to be effective (e.g. addiction therapy programs like duet for convicted alcoholics) [13]. The character of institutions favours creating by penitentiary service special purpose groups for prisoners.

A version of group-work is combining individual actions taken by every social worker with the work done in interdisciplinary teams. The level of complication in convicts' problems is often high, so social workers face the necessity of cooperating with different specialists (e.g. psychologists, psychiatrists and doctors of many other specialties).

The last level of convicts' health care refers to its institutional dimension. Some comment on organizing local communities' health care seems necessary here. Medico-social staff actions in community involve arrangements, but also assistance organizations development and conducting reforms in health service. It is than acting on macro systems, focusing on community organization models and following conclusions for social policy and the process of its administration.

General philosophy of arranging local communities is based on following assumptions:

- Human communities often require help to satisfy their needs in terms of health care. Like individuals needing help to manage these problems. 
- Human communities may develop a capacity of solving their problems, especially those concerning health.

- People wish for change and are able to alter.

- Democracy requires participation in health protection, taking actions concerning community problems and for people to acquire abilities, which enable this participation.

- People should participate in making, adjusting or controlling crucial changes in health protection, in the community premises.

- Changes in communities live, made or prepared by its members, have the meaning and permanence, impossible for imposed ones.

- "Holistic" approach enables dealing with those problems, which are insoluble using "fragmentary" approach. It is crucial for solving health problems. Holistic model of convicts' health care seems to be the most effective for its protection, especially in the process of social reeducation. The standard of its realization depends on society's wealth i.e. possessed funds, and public opinion support in addition. However European public opinion is not always well oriented in the topic. Furthermore, in the beginning of XXI century it becomes a bit populist towards methods of treating criminals, with an attitude rather towards punishing than supporting [14]. This is why the model probably will come to life [15]. However it may not speak against comparison of engaged in convicts' health protection institutions system in "old EU member-countries" and in Poland. This comparison will be the last part of the present paper. It was based on following documents:

- Rapport from conference "L'insertion des jeunes en difficulte et le fonds social europeen. Approche comparee en Europe", chich took place in Vaucreeson near Paris at 15-17.10.2007 (organization: Centre National de Formation et d'Etudes de la Protecion Judiciaire de la Jeunesse).

- Rapport from "Practice into Policy conference”, which took place in London at 20-21.11.2007 (organization: Centre for Economic \& Social Inclusion-London).

I took part in both mentioned.

Furthermore:

- Studies: Prise en charge Medici - psycho - sociale. Ed. Le Comede. Comite Medical pour les exiles. Hopital de Bicetre, Le Cremlin (Paris 2005).

- Administration Penitentiaire. Rapport annual d'activite 2006. Ed. Ministre de la Justice. Paris.

- Le guide de sortant de prison. Observatoire International des prisons. Ed. La Decouverte, Paris 2006.
Analysis presented below is a first stage of comparative analysis mentioned system and Polish institutions, it includes confrontation of information from cited documents and concerning both compared areas.

To characterize present system of health care institutions for convicts in Western Europe it is necessary to notice, that it formed under the influence of tradition developmental social services. Evolution of these services in XXth century in EU countries took place in following 5 basic stages:

- The stage of gradual passage from charity and voluntary work to professional actions (1900-1920).

- The stage of forming working methods based mainly on North-American experiences (1920-1940).

- The stage of inner differentiation of social services, caused by variety of realized tasks (1940-1955).

- The stage of "casework as a basic method of acting" re-discovery (1955-1960).

- The stage of "comprehensive approach" to working methods, based on acting in reliance on group and local communities (after 1960).

French author $\mathrm{C}$. de Robertis notices that equally important moment for social services development, alike to passage from voluntary to professional work, was combining occupation of social assistant and social nurse in one called a social worker. It happened before II World War (in France in 1938) [16]. After II World War to a group of social workers also other specialists and professions working and helping people in difficult situations, which impede integration with society, were included. Although had rather informal character. They were employed in a variety of institutions like social assistance houses and prisons, what caused a fact, that they were not a homogenous group any more, because institutions created new places of actions, aims and tasks.

Currently medico-social staff works with such a heterogeneous group of people needing help and support like: elderly, disabled, homeless, unemployed, mentally distorted, socially unadapted people or criminals etc. The face the problems like children abuse or neglect, lack of care or incapability of elderly people, lack of accommodation, poverty, addiction from drugs or chemical substances and crime. They prepare rapports for courts concerning topics like: health care, treatment possibilities - original and consequent, health support for families, gerontology, possibilities of creating prevention systems, unemployment counter acting etc. In following presentations I'll focus on this group of socio-medical staff, whose aim is convicts' health protection. 
The second important developmental factor for modern convicts' health care institutions system was gradual cessation of private funds for medico-social services. In consequence currently the core of health care institutions for this group is located in a public sector. Still, the sector of societies and foundations is an important "supplement". It seems necessary to emphasize that although means for the institutions are transferred from public funds, both institutions and money are administrated by societies themselves or private persons.

To sum up, current division of health care institutions for convicts contains following categories (Table 1).

Source: author's own study after: Prise en charge Medici - psycho - sociale. Ed. Le Comede. Comite Medical pour les exiles. Hopital de Bicetre, Le Cremlin (Paris 2005) oraz: Le guide de sortant de prison. Observatoire International des prisons. Ed. La Decouverte, Paris 2006.

From above presented table appears that:

- When we compare institutions of health care for convicts in public and societal sector in "old EU member countries" and in Poland it turns out that in first case both sectors developed proportionally. In Poland there are no departmental services in societal sector, what causes that the public sector is a monopolist in the scope of health services for convicts. In the same time public sector in Poland is inefficient in providing health care for all demanding convicts, especially in situation of prisons overpopulation, so it needs a kind of institutional support. One of the possible ways contains table 1 .

- Situation looks much better after analysis of both sectors concerning medical services and institutions supporting departmental medical services. Except medical services in schools the rest of services developed in both - old EU member countries and in Poland, however some differences to the detriment of Poland occur [17]. In our country this sector is less extended, what may be caused by a fact that it develops for a quite short time, furthermore old EU member countries are wealthier, so they have greater funds, which may be allocated in health care.

- Situation referring to sanitary services and social assistance is quite alike. In Poland societal sector, although represented on the level of all services and institutions, except those created by religious congregations, is poor. The reasons are resemble to these presented in point 2 .

It seems that further evolution of health care institutions for convicts judged by common courts will be

Table 1. Institutions of health protection for jurisdiction clients in old EU member countries and in Poland (state from 2006)

\begin{tabular}{|c|c|c|c|c|}
\hline \multirow{3}{*}{ Types of social services } & \multicolumn{4}{|c|}{ Sector's characteristics } \\
\hline & \multicolumn{2}{|c|}{ Public } & \multicolumn{2}{|c|}{ Societal } \\
\hline & $\begin{array}{l}\text { Old EU } \\
\text { members }\end{array}$ & Poland & $\begin{array}{c}\text { Old EU } \\
\text { members }\end{array}$ & Poland \\
\hline \multicolumn{5}{|l|}{$\begin{array}{l}\text { Basic medical and services and institutions } \\
\text { Departmental }\end{array}$} \\
\hline Prisons' medical services & + & + & + & - \\
\hline Juridical medical services & + & + & + & - \\
\hline \multicolumn{5}{|l|}{ Supporting (universal health service - medical services for convicts) } \\
\hline Health care, prevention, and treatment institutions & + & + & + & + \\
\hline Specialist health institutions (specialist hospitals, clinics, mental hospitals, rehab institutions) & + & + & + & + \\
\hline Schools' medical services & + & + & + & - \\
\hline \multicolumn{5}{|l|}{ Sanitary and social assistance institutions } \\
\hline Regional services of social hygiene & + & - & + & - \\
\hline Social actions of Armed Forces & + & - & - & - \\
\hline Municipal services and social assistance offices & + & + & + & + \\
\hline Medical and social services for emigrants and and profit-emigrants & + & + & + & + \\
\hline Charity institutions & - & - & + & + \\
\hline Religous Congregations & - & + & - & - \\
\hline Red Cross & + & + & - & - \\
\hline Others & - & - & + & + \\
\hline
\end{tabular}


connected with both - consolidation of public sector in old EU member countries and more definite state and social support for societal sector in Poland. Practice and hitherto experiences of old EU member countries prove that this sector has large developmental possibilities. It also enables flexibility in administrating health protection institutions and possessed funds, so it is a vital support for health care institutions system traditionally located in old EU countries and in Poland in the public sector.

Table analysis would be incomplete without an indication of the fact that European health care institutions working for jurisdiction may be divided according to the type of environment they act in or according to subordination to the Ministry of Justice. Concerning the latter organizations located formally inside and outside jurisdiction. First group consists of:

- Medico-social services in probation services.

- Medico-social services in educational institutions and reformatories.

- Medico-social services in prisons organized as autonomic services or as a part of probation services.

- In Poland there are no medico-social services in juridical probation service [18]. In second group following European institutions and medico-social services are located:

- Childcare centers,

- Centers of medical and social service for family,

- Institutions and organizations of common health service,

- Mental health clinics,

- Medical and social services for schools.

All kinds of these services are present in Poland.

To sum up, institutions and services included in first group may be named as proper medico - social services in Justice (services medico - sociaux aupres de la Justice), those from the second - supporting (subordinate to Ministries, e.g. Ministry of Public Health; services authorized by Justice - services habilites par la Justice).

In practice these services cooperate closely and their tasks often overlap. It is worth emphasizing that courts may order to both, however the scope of competencies is defined by the law and authorizations done by Minister of Justice (habilitation). It is worth to notice that in the first group public sector services prevail, in case of prisons it has monopoly on medical services for people during imprisonment.

In the majority of Western European countries institutions and organizations dealing with health care of convicts are a part of public sector, while those from societal sector are taking care of cases recognized by courts in a guardianship procedure.

To the complete comparison of present medico-social service systems in old EU member countries and in Poland should be added that in both exists separate network of medico-social services for juveniles and adults subordinate to the Ministries of Justice. In Poland this network is less developed. In France it is a organizational part of great system of legal youth protection, which have in the Ministry of Justice own autonomic General Directory (Protection Judiciaire de la Jeunesse) [19].

To summarize all what has been said in present paper concerning the comparison of institutions of health protection for people, who appear before the court in old EU member countries and in Poland I would like to formulate some more general remarks.

The issue of health care for jurisdiction "clients" obtained great meaning in Western Europe after II World War. It remains an integral part of social and penal policy of single EU member countries. In consequence whole system if medico-social institutions located in public and societal sector are harmonizing. Poland seems to be a bit behind, however in the last few years clear progress is observed. Its determinants are e.g. constant extension of public sector and creating and development of societal sector. This direction should hold, because consequences for jurisdiction are consequences for a whole society.

\section{Acknowledgements}

\section{Conflict of interest statement}

The authors declare that there is no conflict of interest in the authorship or publication of contribution.

\section{Funding sources}

There are no sources of funding to declare.

\section{References}

1. Machel H. Sens i bezsens resocjalizacji penitencjarnej. Casus polski. Kraków 2006.

2. Foucault M. Surveiller et punir. Editio Gallimard 2005.

3. Goffman E. Sigma. Notes on the Management of Spoiled Identity, Harmondsworth. Pelikan Books 1973 (1st edition).

4. Czapów C. Wychowanie resocjalizujące. Warszawa 1980. Czapów C, Jedlewski S. Pedagogika resocjalizacyjna. Warszawa 1971.

5. Stępniak P. Kryzys resocjalizacji penitencjarnej a praca socjalna. Przegląd Więziennictwa Polskiego. 44-45/200.

6. Stępniak P. Praca i pracownicy socjalni w przeciwdziałaniu przestępczości. In: Ambrozik W, Stępniak P (Eds.). 
Służba więzienna wobec problemów resocjalizacji penitencjarnej. Poznań - Warszawa - Kalisz 2004.

7. Preis en charge Medici-psycho-socjale, Le Comede. Comite Medical pour les Exiles. Hopital de Bicetre, Le Cremlin-Bicetre. Ministere des Solidarites, de la Sante et de la Famille.

8. Dubois B, Miley K. Praca socjalna, Warszawa 1996; 156.

9. Rappaport J. Terms of empowering/exemplars of prevention. Toward a theory of gerontological servical services. New York, Columbia University Pres, without publishing date; p. 122.

10. Rappaport J. op. cit. p. 131.

11. Stępniak P. Angielski model pomocy dla więźniów i ich rodzin. Opieka - Wychowanie - Terapia. 1991;1-2.

12. Konopka G. Social group work: A helping process. Englewood Cliffs 1999; 89.

13. Machel H. See: op. cit., pp. 234-241.

14. Salas D. La volonte de punir. Essai sur le populisme penal. Hachette Litteratures 2005 (Paris).

15. Edgy penal populism was seen in Poland during ruling of Jarosław Kaczyński (2005-2007).

16. de Robertis C. Metodyka dzialania w pracy socjalnej. Warszawa 1996; p. 119

17. For recommendations for mentioned services check already cited in footnote no. 6: Prise en charge Medici - psycho - socjale... See also a guide for released convicts:
Le guide du sortant de prison..., pp. 2540275 „Le suivi medical. Le suivi psychiatrique".

18. The bill from 27 July 2001 on probation officers, Dz. U. $\mathrm{Nr}$ 98, poz. 107 with further changes do not stipulate its creating.

19. For details see my paper: Środowisko otwarte jako alternatywa dla więzienia. Z doświadczeń francuskich. Poznań 1997.

Acceptance for editing: 2015-11-10 Acceptance for publication: 2015-12-31

Correspondence address: Piotr Stępniak Poznan University of Medical Sciences email: piotr.stepniak@interia.pl 